\title{
31143006086830
}

\section{THE ART OF WAR}

\section{IN THE MIDDLE AGES}

A.D. 378-1515

\%

Bх C.W.C.Oman

REVISED AND EDITED

BY JOHN H. BEELER

Cornell Paperbacks

\section{CORNELL UNIVERSITY PRESS}

\author{
ITHACA AND LONDON
}




\section{0 355.094 Oma \\ Oman, Charles William \\ Chadwick, Sir, 1860-1946, \\ The art of war in the \\ Middle Ages : A.D. \\ 27R-1515}

Copyright 1953 by Cornell University

All rights reserved. Except for brief quotations in a review, this book, or parts thereof, must not be reproduced in any form without permission in writing from the publisher. For information address Cornell University Press, Sage House, 512 East State Street, Ithaca, New York 14850.

First published, Oxford and Londom, 1885.

Rerised edition, published by permission, 1953.

by Comell University Press.

First printing, (ireat Seal Books, 1960).

Second printing 1963.

Third printing, Comell Paperbacks, 1968.

Tenth printing 1993.

International Standard Book Number ()-8014-9062-6

Printed in the United States of America 